\title{
HARMONIZATION OF ACCOUNTING PRACTICES: THE CASE OF ACCOUNTING FOR PPE IN LITHUANIAN NON-LISTED COMPANIES
}

\author{
Renata Legenzova \\ Vytautas Magnus University, Vilnius, Lithuania \\ Asta Gaigalienè, \\ Vytautas Magnus University, Vilnius, Lithuania \\ Inesa Vilkaite \\ Vytautas Magnus University, Vilnius, Lithuania
}

\begin{abstract}
Accounting harmonization is aimed enhance accounting and information disclosure comparability across and within the countries and by decreasing de jure and de facto variations of such practices and disclosures. Non-listed companies comprising more than $90 \%$ of all the companies in Lithuania and the EU receive very little attention in accounting harmonization related research - such research primarily address issues related to IFRS adoption in listed companies. This paper is aimed to gather the evidence on the accounting practices of Lithuanian non-listed companies in the area of accounting for PPE and to assess the level of their harmonization. To collect information a survey method has been employed and representative sample of Lithuanian non-listed companies' population had been surveyed. Results of the survey reveal that $89.46 \%$ of non-listed companies use cost method to measure PPE after initial recognition; 44.5\% - set a minimum recognition value from 500 to 1000 EUR; $88.5 \%$ - use the straight-line depreciation method; and $68.2 \%$ set a residual value of 1 EUR. In general, the level of harmonization of accounting practices in Lithuanian non-listed companies is above average. Comparability of accounting information across non-listed companies from withincountry perspective is not accomplished.
\end{abstract}

Keywords: accounting harmonization, accounting policy, property plant and equipment (PPE), non-listed companies

\section{JEL classification: M42}

\section{Introduction}

Financial information was and still remains an important source of information about variuos types and sizes of companies in an economy. Information disclosed by an entity is aimed to fulfill information needs of the users, such as investors, creditors, governmental institutions, employees and managers. Although users of financial information may have individual information requirements and preferences, governments and variuos institutions around the globe regulate financial accounting and reporting to accomplish minimum level of business transparency (Soderstorm and Sun, 2007; Schipper, 2005; Barth and Schipper, 2008; Healy and Palepu, 2001). Growth of multinational companies, creation of a single market in the EU as well as increasing efforts to expand such policies worldwide put a presure on policy makers to unify accounting and reporting regulation and practices of business and public sector organizations. Such efforts often refered as accounting harmonization and convergence are aimed to enhance accounting practice and information disclosure comparability by decreasing variations of such practices and disclosures.

Lithuania, as a member of the European Union, has been undergoing major changes in its financial accounting system. As a result of harmonization of accounting regulation Lithuanian listed consolidating companies, banks and other public interest entities are required to use International financial reporting standards (thereafter IFRS), public sector organizations have to use Public sector accounting standards, and the other profit seeking Lithuanian companies are allowed to choose between IFRS or Lithuanian Business accounting standards (thereafter 
Lithuanian BAS). Lithuanian BAS which became in force in 2004 are constantly reviewed and updated according to the business requirements and changes in accounting regulation in the EU. They may be treated as simplified version of IFRS, especially in the area of accounting for PPE. Based on the information provided to Lithuanian Registry of Companies the absolute majority of Lithuanian profit seeking companies chooses Lithuanian BAS to account and report for their business activities. As of 2015 more than 60 thousand of Lithuanian companies that provided their financial statements to the Registry of Companies identified using Lithuanian BAS as their choice of accounting standards, while just around 120 companies identified using IFRS. On the other hand, during the same period more than 10 thousand active companies did not present their financial statements to the Registry of Companies at all, which also raises an issue of supervision and quality assurance in financial accounting and reporting.

Literature analysis revealed that accounting harmonization is a complex process, which attracts attention of numerous accounting researchers worldwide. Research papers approach this process from either de jure (of regulation) or de facto (of practices) harmonization perspective and aim to evaluate either its across-country or within-country outcomes. An overview of accounting harmonization related scientific research allows concluding that a substantial part of such research is associated with regulatory and practical issues of IFRS adoption (Amstrong et. al., 2010; Brochet et.al., 2013; Ding and Su, 2008; Baker and Barbu, 2007). The other mainstream of scientific research addresses compliance of national accounting standards with IFRS requirements (Strouhal et al., 2011; Buculescu and Velicescu, 2014). However, studies aiming to understand accounting and reporting practices of national-standards' using companies are very limited. Based on the facts that the EU is dominated by small and medium businesses (comprising an average of $91 \%$ of total EU companies) and most of the EU member states have their own accounting standards (IFRS use around the world, 2016), harmonization situation of the substantial part of publicly disclosed financial information is unclear. Lack of the evidence on national accounting harmonization practices might be related to the limited access of organized and publicly available information on non-listed companies. It may also reflect undervaluation and perceived insignificance of small and medium companies in accounting and financial research.

This paper is aimed to present the evidence on the accounting practices of Lithuanian nonlisted companies in the area of accounting for property plant and equipment (thereafter PPE) and, based on such evidence, to assess the level of harmonization of accounting practices among Lithuanian non-listed companies.

To collect information on accounting practices in non-listed companies a survey of accounting policy choices for PPE in Lithuanian non-listed companies has been conducted. To assess harmonization of accounting practices in Lithuania, accounting for PPE had been chosen intentionally as such assets normally exist in the majority of companies and comprise a substantial part of all assets; accounting policy choices for PPE are clearly identifiable and might be chosen irrespective of the sector or industry.

\section{Literature review}

To overview related literature some questions of harmonization of accounting in general and in the area of PPE were addressed: what type of companies (ie listed or non-listed) were analyzed in previous research, what type of accounting standards were used by the analyzed companies, what kind of harmonization has been analized (de jure or de facto), and is there any scientific research related to accounting harmonization of PEE? 
Literature analysis revealed that scientific research addressing harmonization of accounting practices is limited and fragmented. Scientific research related to harmonization of accounting regulation dominates over the research related to harmonization of accounting practices. The level of harmonization of PPE's accounting policy choices in listed companies is analyzed to some extent and primarily in relationship with harmonization of accounting regulation. No prior research related to assessment of harmonization of accounting practices in non-listed companies has been found. It applies both to accounting for PPE and accounting policy choices in general.

In regards of harmonization of accounting regulation in Central and Eastern Europe Strouhal et al. (2011) compared national accounting standards of the Czech Republic, Estonia, Latvia and Romania with IFRS, looked at approaches of these countries to aspects of financial reporting, and analyzed differences and similarities using Jaccard's association coefficients as a general tool. The results of the analysis revealed that the most compatible systems with international referential are accounting systems of Baltic countries. Buculescu and Velicescu (2014) conducted a comparative analysis between IFRS for SMEs and Romanian national accounting regulations concerning measurement of formal convergence level of definitions, treatment and policies of PPE and concluded on medium level of convergence between the two regulations in the area of PPE.

Kvaal and Nobes (2010) and (2012) investigated whether pre-IFRS national practice continues after the adoption of IFRS by using information from annual reports of companies from countries that have the largest five stock markets (UK, Germany, Australia, France and Spain). Their results present strong evidence that the choices among IFRS policy options can largely be explained by the continuation of a company's pre-IFRS policies. Morais (2008) examined financial statements of 523 listed European companies in order to identify the accounting method of actuarial gains and losses followed by companies after the mandatory adoption of IFRS. His findings indicate that most of European companies choose similar accounting policies as majority of sample companies adopted the corridor method or the equity recognition method rather than the profit or loss method. Bahadir and Tolga (2013) examined IFRS-based financial reports of 235 Turkish listed companies with reference to 11 accounting policy choices they made relating to options permitted by IFRSs and found a significant degree of heterogeneity among the behaviors of Turkish listed companies with regard to choices concerning measurement model for property, plant and equipment and measurement model for investment property. Astami and Tower (2006) examined four key accounting-policy disclosures in the annual reports of listed companies in the Asia Pacific region to assess income increasing (decreasing) accounting-policy choice tendency and determined differences among the companies.

\section{Accounting for PPE under Lithuanian BAS}

Under the current status of accounting regulation Lithuania, as the EU member state, uses 3 sets of accounting standards: IFRS - for listed companies consolidating their financial statements, other public interest companies (such as banks) and other types of companies which choose to use IFRS voluntary; national Business accounting standards (BAS) - for other business entities not included in the first group (irrespective of their size, legal status and industry); and public sector accounting standards - for governmental institutions and nonprofit organisations. According to the 3th article of the Law on Accounting (2001) Lithuanian BAS are prepared by Accounting Standards Setting Committee and approved by the Minister of Finance of the Republic of Lithuania. These standards have to comply with the EU regulation and IFRS. Lithuanian BAS first became in force for the financial year 2004. As of October 2016 a total of 42 Lithuanian BAS are used (see www.aat.lt for a list and English 
translation of Lithuanian BAS). Lithuanian BAS are reviewed periodically to reflect the needs of the market and changes in the EU regulation - i.e. the last major revision of Lithuanian BAS is related to new 20130626 European Parliament and Commission's Directive 2013/34/ES when more than 20 existing Lithuanian BAS were amended.

In Lithuania PPE is referred to as non-current tangible assets. The concept is defined in BAS 2 "Balance sheet", while accounting and reporting for PPE is regulated under BAS 12 "Noncurrent tangible assets". To account and report for PPE companies also have to apply requirements of other BAS, such BAS 23 "Impairment of assets", BAS 32 "Setting fair value", BAS 20 "Operating lease, finance lease and loan-for-use".

Lithuanian BAS 2 defines that any asset shall be classified as non-current asset if it is used by an entity for a period longer than one year in order to obtain economic benefits. Under Lithuanian BAS 12 a tangible asset shall be attributed to non-current assets when it meet all of the conditions: a) the entity expects to use it for a period longer than one year; b) the entity reasonably expects a flow of economic benefits from such asset in future periods; c) the entity can reliably measure the acquisition (production) cost of the asset; d) the acquisition (production) cost of the asset exceeds the minimum cost of a non-current tangible asset set by the entity for each group of assets; e) risk related to tangible asset has been transferred to the entity. To compare with International Accounting standard (IAS) 16 "Property, plant and equipment" - Lithuanian BAS 12 introduces an additional requirement - a minimum value of an asset. In Lithuania the requirement to set a minimum value of an asset originates from tax accounting requirements. A minimum value of PPE defines recognition of an item as an expense or as an asset in the period it occurred - therefore it may have a material influence on the financial results and position of a company.

Similar to IAS 16, upon initial recognition under Lithuanian BAS 12 a non-current tangible asset is accounted at cost. Such costs comprise cash amount paid or payable (or the value of other consumed asset) upon the acquisition of the asset; delivery costs; customs, excise duties and other non-recoverable taxes; costs of planning work; assembly costs; installation costs; costs of preparation for use; costs of repairs carried out before the asset is brought into use; testing costs; infrastructure and asset registration costs; costs of plot and construction site preparation; estimated costs of dismounting and removing the asset and restoring the site; other costs directly related to the acquisition of assets. Items such, as interest expenses, administrative expenses, etc. are not included into acquisition cost.

Non-current tangible assets are grouped according to their similar nature and use in the entity's activities. For accounting purposes number and types of asset groups are determined at the discretion of an entity. Lithuanian Registry of Companies required certain typical classification of PPE for reporting purposes, therefore companies are expected to choose classification provided in BAS 12: land and right to it, buildings and rights to them, plant and machinery, vehicles, equipment, assets under construction, investment property, other noncurrent tangible assets.

After the initial recognition, an entity is allowed to select an accounting policy to carry noncurrent tangible assets at the acquisition cost or the revaluation amount. Separate groups of assets may be recorded applying different accounting methods. All non-current tangible assets have to be annually tested for impairment. Rules for accounting for PPE after initial recognition and rules for impairment testing under Lithuanian BAS are similar to those in IAS 19 and other IFRS's.

According to BAS 12 non-current tangible assets can be of a finite and indefinite useful life. Land represents asset with indefinite useful life, so its depreciation is not calculated. It is required to calculate depreciation for assets with finite useful life according to one of the 
following methods: straight-line method, units-of-production method, sum-of-years' digits method, and double declining balance method. One of the BAS 12 requirements which is stricter than in IAS 16 is related to the beginning and ending of depreciation's calculations: depreciation is calculated from the 1st day of the next month after a non-current tangible asset is brought into use and discontinued as from the 1st day of the next month after its written-off. Criteria for calculating depreciation amount under BAS 12 are the same as under IAS 16. It could be noted that useful life of an asset and its residual value are the main decision areas where company's accounting policy choices may have a substantial influence of reporting of financial position and results of the company. Similar to IFRS, Lithuanian BAS does not prescribe strict guidelines on how to make these decisions.

To summarize accounting for PPE (or non-current tangible assets, as they are called in Lithuania) is mainly regulated by Lithuanian BAS 12. Requirements of BAS 12 may be grouped into: principle based accounting policy choices (such as minimum value for PPE recognition, depreciation method, useful life, residual value, classification of assets) and strict rules (such as calculation of acquisition costs, beginning and ending period for depreciation calculation, requirement for impairment testing, etc.) A comparative analysis of Lithuanian BAS 12 and IAS 16 revealed no major differences in regulation of this area (except for the above mentioned minimum value for recognition of PPE) - therefore de jure harmonization of PPE accounting regulation for all type of profit-seeking entities is achieved.

\section{Research methodology}

Lack of the evidence on accounting policy choices of non-listed companies and harmonization of such choices verified a need for the research. The research was aimed to collect evidence on PPE accounting policy choices of Lithuanian non-listed companies (step 1) and based on such evidence to assess harmonization of accounting practices in Lithuania among non-listed companies (step 2).

For step 1 the quantitative questionnaire research method has been chosen due to limited availability of the existing data for this type of research. The questionnaire was constructed from the selected closed-type questions designated to collect information on the PPE accounting policy choices in Lithuanian non-listed companies. This type of questions was prioritized due to their better precision and higher comparability of the results, which is necessary for quantitative analysis, and comparison of collected data.

Questionnaire. The research questionnaire included 9 questions. Three questions were designed for identification of a company's characteristics (such as company size, industry sector and juridical status) and the remaining 6 questions were targeted at the specific areas of PPE accounting policy choices of Lithuanian non-listed companies. Questions 1-3 were necessary for verifying the compliance of the results with the targeted research sample. The questions 4-9 were targeted at gathering the data on PPE accounting policy choices such as what depreciation method is applied, what is PPE accounting model after recognition (acquisition costs or revalued amount), what is the estimated useful life of an assets and what is its residual value. The structure and content of the questionnaire were based on the earlier research in this field by other authors as well as theoretical insights. (The questionnaire is available upon request). The closed-type questions were formulated in accordance with the Lithuanian BAS 12 as well as in compliance with Lithuanian Profit tax law and subsequent orders of the Government of Lithuanian Republic.

Sampling. The representative research sample is imperative for the success of every empirical research. The authors of this paper determined the sample size according to probability, simple random sampling technique when the sample is selected taking into account the 
dominant characteristics of the researched population. This type of sampling is favorable as the probability for every population member to be included into research is known beforehand and the research results can be extended for the case of general population. According to the Department of Statistics of Lithuanian Republic, 118,544 business entities were registered in Lithuania at the beginning of 2016. Such general population (50,000 and more elements) is considered to be large. Empirical research was conducted with the 95 percent confidence level, 5 percent margin of error and 10 percent of sample proportion. The sample size was calculated accordingly:

$$
n=\frac{1.96^{2} * 118,544 * 0.1(1-0.1)}{0.05^{2}(118,544-1)+1.96^{2} * 0.1(1-0.1)}=138 \text { respondents }
$$

$\mathrm{n}$ - sample size;

$\mathrm{N}$ - general population;

$\mathrm{Z}$ - critical value of $\alpha$ level of standard normal distribution $\mathrm{N}(0,1)$;

$\mathrm{p}$ - sample proportion;

e - margin of error (maximum deviation of the selected sample from the true characteristics of the entire population).

In order to ensure the representative research results, the size, juridical status and sectorial distribution of Lithuanian companies was also taken into account when determining the sample size and structure. According to the Department of Statistics of Lithuanian Republic, at the beginning of $201614.1 \%$ of all Lithuanian companies operated in the manufacturing sector, $83.5 \%$ - in the service sector and $2.4 \%$ in agricultural sector. Therefore, the questionnaires were distributed to the corresponding number of companies from each sector trying to maintain the described sectorial proportion.

Timeline and distribution. The research data was collected with the help of survey method. The questionnaire was uploaded in a special web site and the link was distributed to the targeted auditorium by e-mail with the assistance of PLLC "BDO auditing and accounting" and PLLC "Docinta". These two companies were selected as intermediaries because of their wide business-to-business networking with Lithuanian companies of a various size. The survey was conducted over the period of March 15 - April 2, 2016.

Limitations of the research. In every empirical research it is imperative to take the limitations that can arise during its performance into account. It is important to point out the research limitations, as they may influence the reliability of the results and their interpretation. It is important to note that there could be a chance of error in sampling as the respondents' structure could not match the projected sample structure and not fully represent the accounting policy choices of all Lithuanian non-listed companies. The second limitation could be caused by the data collecting method. As the survey method always leaves a possibility to misinterpretation of questions by respondents or not correctly disclosed information. This can also influence the reliability and interpretation of the research results.

In the step 2 in order to assess the level of accounting harmonization practices a qualitative evaluation of the research data for step 1 will be conducted. The level of accounting harmonization will be considered as being very high if the same choice of PPE accounting policy in each assessed areas (minimum amount, measurement after recognition, depreciation method, useful life and residual value) will receive an average score of more than $75 \%$ (number of companies using certain accounting policy as of total companies); higher than an average - if the score will range between $75-50 \%$, below average - if it will vary below $50 \%$ and above $25 \%$, and very low if it scores less than $25 \%$. The overall assessment of the level of 
harmonization will be based on the consistency of accounting policy choices and the dominating quartiles (in \%) in the accounting policy choices for each alternative.

\section{PPE accounting policy choices by Lithuanian non-listed companies}

Descriptive statistics: In order to collect data for accounting policy choices by Lithuanian non-listed companies' research, 492 respondents were targeted with the specifically designed questionnaires. A total of 140 questionnaires were answered by representatives of the Lithuanian non-listed companies and returned for further processing. The rate of the questionnaire return was $28.5 \%$. The number of returned questionnaires was sufficient for the research representativeness (see research sampling); the collected data was used for analysis and further interpretation.

The returned questionnaires were from companies of different juridical status. $60.3 \%$ of respondents were private limited liability companies (PLLC). It is important to note that such rate of involvement of private limited liability companies into research partly represents the Lithuanian market realities. According to the Department of Statistics of Lithuanian Republic, in the year 2015 the number of private limited liability companies totaled to $67 \%$ of all business entities in Lithuania. The remaining respondents distributed across the other juridical statuses almost equally. $14 \%$ of respondents are incorporated as non-listed joint stock companies (JSC), $12.5 \%$ as public establishments and $11 \%$ as other juridical forms.

The sectorial distribution of respondents was also important in order to correctly represent the Lithuanian businesses. $5.1 \%$ of respondents were companies operating in sector of agriculture, $14 \%$ of manufacturing sector, $54.4 \%$ of service sector and the remaining $29 \%$ identified operating in more than one sector. The research sample represents all the sectors proportionally to real situation in economy, despite the slightly larger proportion of agricultural companies. The respondents represent different sizes of companies, where the size is interpreted as the number of employees. $32.4 \%$ of respondents were small companies (from 10 to 49 employees), 25\% were medium sized companies (from 50 to 249 companies), $21.3 \%$ were big companies (more than 250 employees) and $21.3 \%$ were micro companies (from 1 to 9 employees). As the number of returned questionnaires as well as the structural characteristics (representation of company size, industry and juridical status) of the sample was sufficient for research representativeness (see research sampling), the collected data was used for analysis and further interpretation.

The presence of written PPE accounting policy. In order to deeper analyze the peculiarities of PPE accounting policy in Lithuanian non-listed companies, it was important to find out how many respondents have a written PPE accounting policy's guidelines and use them in their daily activities. The results of analysis allowed to conclude that majority (91.3\%) of the sample companies had the written guidelines for PPE accounting policy. However, despite legal obligations, a relatively big part $(8.7 \%)$ of companies indicated working with no prepared policy guidelines.

PPE measurement after initial recognition. The respondents were asked to indicate which accounting policy alternatives are used for different PPE groups: land, buildings, machinery and equipment, vehicles and other PPE.

The analysis of the results (see Figure 1) indicated that Lithuanian companies tended to apply acquisition cost method more often than revaluation method for PPE measurement subsequent to initial recognition. On average acquisition cost method for PPE measurement after initial recognition was applied by $89.46 \%$ of respondents. More detail analysis of the results revealed some differences in assets value measurement method choices for different PPE groups. The acquisition cost method was preferred by $84.3 \%$ of respondents for land value 
measurement, by $80 \%$ of respondents for measurement of buildings' value, by $92.7 \%$ for accounting machinery and equipment, 94.6\% companies used it to account vehicles and 95.3\% to account other PPE. The PPE was measured by revalued amount method less often. $10.54 \%$ of companies indicated using the latter method in their financial accounting practices. It is worth noticing that revalued amount method is most often chosen to register the value of buildings (20\%) and land (15.7\%).

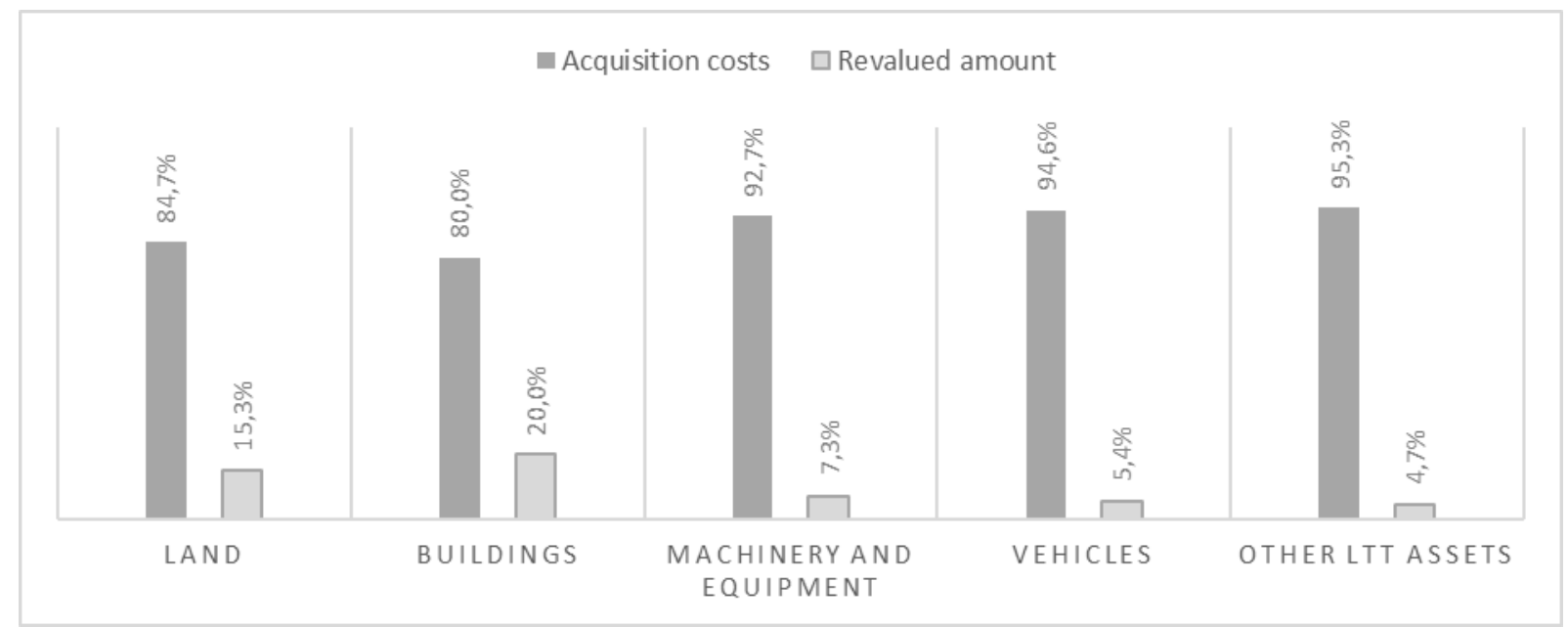

Figure 1. Accounting policy choices for PPE measurement after initial recognition by Lithuanian non-listed companies (\% of total companies)

Minimum value for recognition of PPE. Another aspect of accounting policy where differences in Lithuanian non-listed companies might arise is the minimum value of PPE and separate asset groups. As presented in Figure 2 the most of Lithuanian companies set the minimum value for recognizing PPE from 500 to 1,000 EUR and in overall $44.5 \%$ of companies' representatives indicated that they use this value in their accounting. Analysis of the results by the classes of assets show that $46.9 \%$ companies chose the amount from 500 to 1,000 EUR to recognize land and 51.9\% of respondents - for machinery and equipment. Fewer companies applied it for recognizing buildings (38.2\%) vehicles (48.4\%), and other PPE (37.1\%). Respondents indicated the minimum value of less than 500 EUR most often is used for other PPE. The highest but the least used minimum value exceeding 1,000 EUR is set for buildings (applied by $31.5 \%$ of companies).

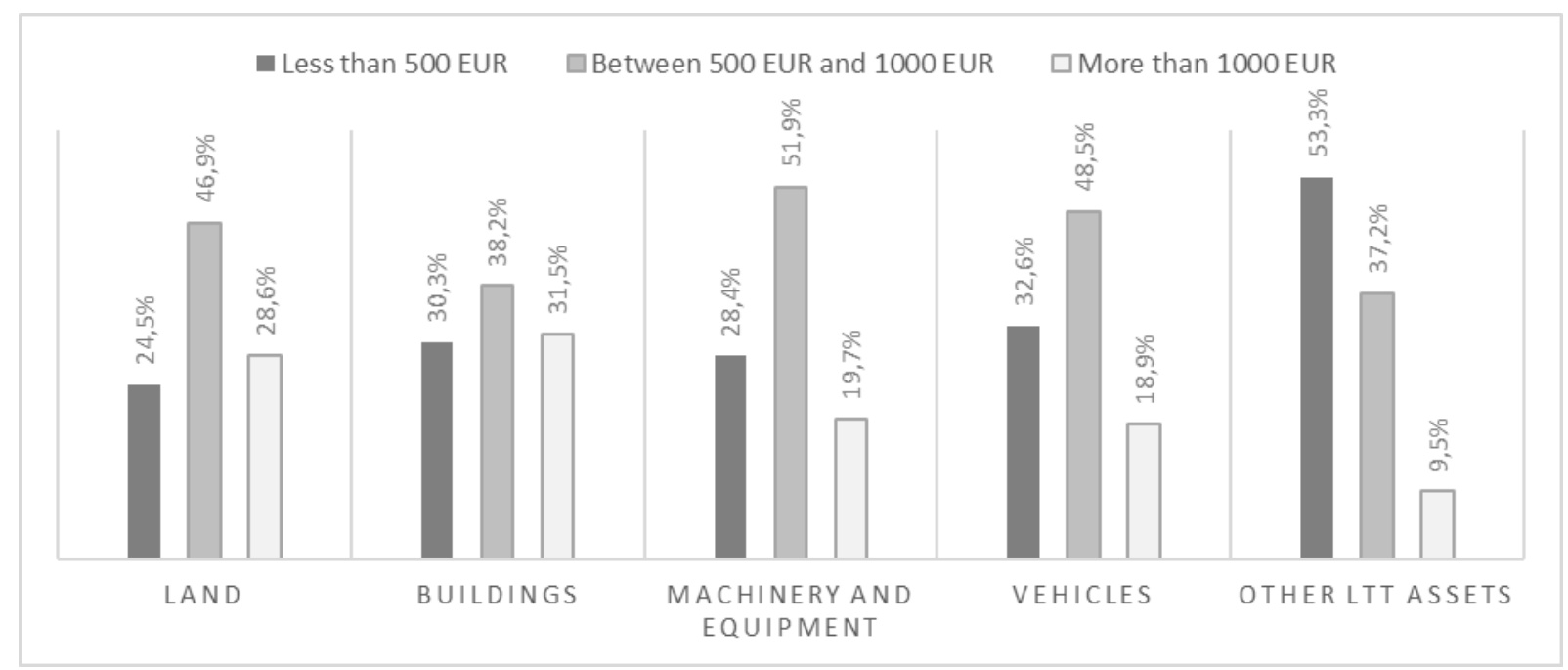

Figure 2. Minimum value for PPE recognition in Lithuanian non-listed companies (\% of total respondents) 
PPE depreciation method. One of the most important PPE's accounting policies influencing profitability of a company is assets' depreciation method. In this case the results represent not only the accounting policy choices by Lithuanian companies but also a compliance of financial accounting with tax accounting. As presented in Table 1 majority of Lithuanian companies chose the straight-line depreciation method, which is set both in Lithuanian BAS and Profit Tax Law (2001). On average, this method was chosen by $88.5 \%$ of respondents and dominated in all asset groups: machinery and equipment (86.7\%), vehicles (88.4\%) and other PPE (90.7\%) Accelerated depreciation methods such as sum-of-the-years-digits method and double declining balance method are much less used $(8.9 \%$ and $0.83 \%$ of all the companies respectively).

Estimated useful life of PPE. The analysis of the statistics of respondents' choices on assets estimated useful life periods (see Table 1) revealed that the estimated useful life of assets differ depending on a class of PPE. For example, 65.5\% of respondents set a useful life of buildings longer than 20 years, while vehicles are considered to be useful for the periods up to 10 years by $68.7 \%$ of Lithuanian companies. Some companies chose very short useful life for their PPE - up to 5 years' useful life of buildings was chosen by $1.1 \%$ of companies; up to 3 years - for accounting machinery and equipment (5\% of companies) or vehicles $(2.2 \%$ or companies). Such choices are non-compliant with tax regulation, so, most probably, it explains a low number of companies using those policies.

Table 1. Results of the survey on PPE accounting policy choices by Lithuanian non-listed companies (\% of total respondents)

\begin{tabular}{|l|c|c|c|c|}
\hline $\begin{array}{c}\text { Accounting policy choices for PPE } \\
\text { depreciation method (\% of all respondents) }\end{array}$ & Buildings & $\begin{array}{c}\text { Machinery } \\
\text { and equipment }\end{array}$ & Vehicles & Other PPE \\
\hline Straight line & $88.2 \%$ & $86.7 \%$ & $88.4 \%$ & $90.7 \%$ \\
\hline Units-of-production & $3.2 \%$ & $0.0 \%$ & $2.1 \%$ & $1.9 \%$ \\
\hline Sum-of-the-year's-digits & $8.6 \%$ & $12.0 \%$ & $8.4 \%$ & $6.5 \%$ \\
\hline Double declining balance & $0.0 \%$ & $1.3 \%$ & $1.1 \%$ & $0.9 \%$ \\
\hline $\begin{array}{c}\text { Accounting policy choices for PPE estimated } \\
\text { useful life (\% of all respondents) }\end{array}$ & Buildings & $\begin{array}{c}\text { Machinery } \\
\text { and equipment }\end{array}$ & Vehicles & Other PPE \\
\hline Up to 3 years & $0.0 \%$ & $5.0 \%$ & $2.2 \%$ & $18.7 \%$ \\
\hline Up to 5 years & $1.1 \%$ & $27.5 \%$ & $22.6 \%$ & $40.2 \%$ \\
\hline Up to 10 years & $12.6 \%$ & $41.2 \%$ & $68.7 \%$ & $33.6 \%$ \\
\hline Up to 20 years & $20.8 \%$ & $18.8 \%$ & $6.5 \%$ & $4.7 \%$ \\
\hline More than 20 years & $65.5 \%$ & $7.5 \%$ & $0.0 \%$ & $2.8 \%$ \\
\hline $\begin{array}{l}\text { Accounting policy choices for PPE residual } \\
\text { value (\% of all respondents) }\end{array}$ & Buildings & $\begin{array}{c}\text { Machinery } \\
\text { and equipment }\end{array}$ & Vehicles & Other PPE \\
\hline 1 EUR & $58.0 \%$ & $68.8 \%$ & $71.1 \%$ & $74.8 \%$ \\
\hline From 1 EUR to 10\% of acquisition cost & $17.0 \%$ & $12.4 \%$ & $14.5 \%$ & $15.5 \%$ \\
\hline 10\% of acquisition cost & $20.5 \%$ & $15.0 \%$ & $13.3 \%$ & $9.7 \%$ \\
\hline More than 10\% of acquisition cost & $4.5 \%$ & $3.8 \%$ & $1.1 \%$ & $0.0 \%$ \\
\hline
\end{tabular}

Residual value of PPE. As presented in Table 1 PPE accounting policy choices of in Lithuanian non-listed companies revealed that the residual value of 1 EUR is the most often used accounting policy (68.2\% of all cases). No significant differences in setting the residual value for different PPE classes were noticed. The residual value of 1 EUR is most often used in accounting of all PPE groups: buildings (58\%), machinery and equipment $(68.8 \%)$, vehicles $(71.1 \%)$ and other PPE $(74.8 \%)$. The residual values higher than 1 EUR were chosen less frequently. $14.75 \%$ of respondents pointed out that they choose residual values of $10 \%$ of the acquisition cost and only $2.35 \%$ tend to use residual values that are higher that $10 \%$ of the acquisition cost. 


\section{An assessment of harmonization of PPE accounting practices in Lithuanian non-listed companies}

To assess the level of de facto harmonization of PPE accounting practices the survey data has been summarized in Table 2 and a qualitative assessment of the accounting policy choices by Lithuanian non-listed companies was conducted.

Results of the assessment allow concluding that Lithuanian non-listed companies do not choose identical accounting policy choices and differences in their accounting for PPE exist, which could lead to different financial results and financial position for the companies operating in identical situations. Moreover, companies do not make the same accounting policy choices across different classes of assets, which could be explained by differences in characteristics and usage of the assets as well as nature of the companies' business. Based on the information presented in Table 2, "a typical" Lithuanian non-listed company most feasibly will recognize PPE when its acquisition cost exceeds 500 EUR, will depreciate it using straight line method to 1 EUR residual value and will use a cost method for its accounting after initial recognition.

Table 2. An assessment of harmonization of accounting practices for PPE among Lithuanian non-listed companies

\begin{tabular}{|c|c|c|c|c|c|}
\hline \multirow{2}{*}{$\begin{array}{c}\text { PPE classes/ } \\
\text { Assessment }\end{array}$} & \multicolumn{4}{|c|}{ Dominating accounting policy choice (\% of companies choosing it) } \\
\cline { 2 - 6 } & $\begin{array}{c}\text { Minimal value for } \\
\text { recognition }\end{array}$ & $\begin{array}{c}\text { Measurement } \\
\text { after recognition }\end{array}$ & $\begin{array}{c}\text { Depreciation } \\
\text { method }\end{array}$ & $\begin{array}{c}\text { Useful life } \\
\text { Residual } \\
\text { value }\end{array}$ \\
\hline Land & $\begin{array}{c}500-1,000 \text { EUR } \\
(46.9 \%)\end{array}$ & $\begin{array}{c}\text { At cost } \\
(84.7 \%)\end{array}$ & n/a & n/a \\
\hline Buildings & $\begin{array}{c}500-1,000 \text { EUR } \\
(38.2 \%)\end{array}$ & $\begin{array}{c}\text { At cost } \\
(80.0 \%)\end{array}$ & $\begin{array}{c}\text { Straight line } \\
(88.2 \%)\end{array}$ & $\begin{array}{c}>20 \text { years } \\
(65.5 \%)\end{array}$ & $\begin{array}{c}1 \text { EUR } \\
(58.0 \%)\end{array}$ \\
\hline Machinery and equipment & $\begin{array}{c}500-1,000 \text { EUR } \\
(51.9 \%)\end{array}$ & $\begin{array}{c}\text { At cost } \\
(92.7 \%)\end{array}$ & $\begin{array}{c}\text { Straight line } \\
(86.7 \%)\end{array}$ & $\begin{array}{c}>10 \text { years } \\
(41.2 \%)\end{array}$ & $\begin{array}{c}1 \text { EUR } \\
(68.8 \%)\end{array}$ \\
\hline Vehicles & $\begin{array}{c}500-1,000 \text { EUR } \\
(48.5 \%)\end{array}$ & $\begin{array}{c}\text { At cost } \\
(94.6 \%)\end{array}$ & $\begin{array}{c}\text { Straight line } \\
(88.4 \%)\end{array}$ & $\begin{array}{c}>10 \text { years } \\
(68.7 \%)\end{array}$ & $\begin{array}{c}1 \text { EUR } \\
(71.1 \%)\end{array}$ \\
\hline Other PPE & $\begin{array}{c}\text { Less } 500 \text { EUR } \\
(53.3 \%)\end{array}$ & $\begin{array}{c}\text { At cost } \\
(95.3 \%)\end{array}$ & $\begin{array}{c}\text { Straight line } \\
(90.7 \%)\end{array}$ & $\begin{array}{c}>5 \text { years } \\
(40.2 \%)\end{array}$ & $\begin{array}{c}1 \mathrm{EUR} \\
(74.8 \%)\end{array}$ \\
\hline Overall & $\begin{array}{c}500-1,000 \mathrm{EUR} \\
(44.5 \%)\end{array}$ & $\begin{array}{c}\text { At cost } \\
(89.46 \%)\end{array}$ & $\begin{array}{c}\text { Straight line } \\
(88.5 \%)\end{array}$ & $\begin{array}{c}1 \mathrm{EUR} \\
(68.2 \%)\end{array}$ \\
\hline $\begin{array}{c}\text { Consistency of accounting } \\
\text { policy among PPE classes }\end{array}$ & Mostly yes & yes & yes & no & Yes \\
\hline Harmonization of & $\begin{array}{c}\text { Below } \\
\text { average }\end{array}$ & $\begin{array}{c}\text { Above } \\
\text { average }\end{array}$ & $\begin{array}{c}\text { Above } \\
\text { average }\end{array}$ & Average & $\begin{array}{c}\text { Above } \\
\text { average }\end{array}$ \\
\hline
\end{tabular}

All the analyzed Lithuanian non-listed companies use Lithuanian BAS. However, results of the survey revealed that harmonization of accounting regulation (i.e. using the same accounting standards) do not lead to the harmonization of accounting practices. In case of PPE accounting, the qualitative assessment of de facto accounting harmonization varied from above average to average and below average (as presented in Table 2). The overall score of the harmonization is assigned as above average as the majority of the PPE accounting areas received such evaluation. In Lithuania ccomparability of non-listed companies' accounting information from within-country perspective is not accomplished. On the other hand, financial information about the company has to be relevant and faithfully represented and to show true and fair view about a company. Hence, an accounting method that is appropriate to the company's operating circumstances rather than the use of the same method by all companies has to be encouraged. 


\section{Conclusions}

Accounting harmonization is aimed enhance accounting practice and information disclosure comparability among any size and type of companies across and within the countries and by decreasing de jure and de facto variations of such practices and disclosures. Scientific research addressing harmonization of accounting practices is limited and fragmented and primarily addresses issues related to IFRS adoption in listed companies. No prior research related to assessment of harmonization of accounting practices for PPE or in general in nonlisted companies has been found.

In Lithuania accounting for PPE is regulated under Lithuanian BAS. A comparative analysis of Lithuanian BAS 12 and IAS 16 requirements revealed no major differences in regulation of accounting for PPE. Requirements of Lithuanian BAS 12 define both: principle-based accounting policy choices (such as minimum value for PPE recognition, depreciation method, useful life, residual value, classification of assets) and strict rules (calculation of acquisition costs, beginning and ending period for depreciation calculation, requirement for impairment testing, etc.) Existence of principle-based accounting policy choices under Lithuanian BAS creates a possibility of differences in accounting practices of Lithuanian BAS-using companies.

The survey conducted across 140 of Lithuanian non-listed companies was aimed to gather the evidence on the accounting practices of such companies in the area of accounting for PPE and, based on the results of the survey, to assess the level of their harmonization. Results of the survey identified the dominant companies' choices of accounting policy choices in different PPE areas and the areas where most differences occurred. It reveal that $89.46 \%$ of non-listed companies prefer cost method to measure PPE after initial recognition rather than revaluation method; 44.5\% - set a minimum recognition value from 500 to 1,000 EUR; $88.5 \%$ - use the straight-line depreciation method although accelerated deprecation methods are also used; the residual value of 1 EUR was the most popular choice by $68.2 \%$ of companies, and no significant differences in residual value for different PPE groups exist.

In Lithuania harmonization of accounting regulation does not lead to the harmonization of accounting practices across non-listed companies, as companies do not choose identical PPE's accounting policy choices. Interpretation of the results allow concluding that in general the level of harmonization of accounting practices in Lithuanian non-listed companies is above average, differences across the groups of assets and across the companies exist and comparability of accounting information from within-country perspective is not yet accomplished.

\section{Literature}

Armstrong, Ch. S., Barth, M. E., Jagolinzer, A. D., Riedl E. J., (2010). Market reaction to the adoption of IFRS in Europe. The Accounting Review, vol. 85, no.1, pp. 31-61.

Astami, E., Tower, G. (2006). Accounting-policy choice and firm characteristics in the Asia Pacific region: An international empirical test of Costly Contracting Theory. The International Journal of Accounting, vol. 41, no. 1, pp. 1-21.

Bahadir, O., Tolga, B. (2013). Accounting policy options under IFRS: evidence from Turkey. Accounting and Management Information Systems, vol. 12, no. 3, pp. 388-404.

Baker, R., Barbu, E .M. (2007). Trends in research on international accounting harmonization. International Journal of Accounting, no. 42, pp. 272-304.

Barth, M., Schipper, K. (2008). Financial Reporting Transparancy. Journal of Accounting, 
Auditing \& Finance, vol 23, no. 2, pp. 173-190.

Brochet, F., Jagolinzer, A., Riedl, E. (2013). Mandatory IFRS adoption and financial statement comparability. Contemporary Accounting Research, vol. 30, pp. 1371-1400.

Buculescu, M.M., Velicescu, B. A. (2014). An analysis of the convergence level of tangible assets (PPE) according to Romanian national accounting regulation and IFRS for SME. Accounting and Management Information Systems vol. 13, no. 4, pp. 774-799.

Ding, Y., Su, X. (2008). Implementation of IFRS in a regulated market. Journal of Accounting and Public Policy, vol. 27, no. 6, pp. 474-479.

Healy, M. P., Palepu, K. G. (2001). Information Asymetry, Corporate Disclosure and the Capital Markets: A Review of the Empirical Disclosure Literature. Journal of Accounting and Economics. Vol. 31.

IFRS use around the world.

Available on-line at: http://www.ifrs.org/Use-around-the-world/Pages/Jurisdictionprofiles.aspx

Kvaal, E., Nobes C. W. (2010). International differences in IFRS policy choice: a research note. Accounting and Business Research, vol. 40, no. 2, pp. 173-187.

Kvaal, E., Nobes, C. W. (2012). IFRS policy changes and the continuation of national patterns of IFRS practice. European Accounting Review, vol. 21, no. 2, pp. 343-371.

Morais, A. I. (2008). Actuarial gains and losses: the choice of the accounting method. Accounting in Europe, vol. 5, no. 2, pp. 127-139.

Strouhal, J., Bonaci, C., Mustata, R., Alver, L., Alver, J., Praulinš, A. (2011). Accounting Harmonization Measurement: Case of Emerging CEE Countries. International Journal Of Mathematical Models And Methods In Applied Sciences, vol. 5, issue 5, pp. 889-906.

Schipper, K. (2005). The introduction of international accounting standards in Europe: implications for international convergence. European Accounting Review, vol. 14, no.1, pp. 101-126.

Söderström, N. S., Sun, K. J. (2007). IFRS adoption and accounting quality: a review. European Accounting Review, vol. 16, no. 4, pp. 675-702. 